\title{
FAMILY HARMONY IN IMPLEMENTATION OF POHUTU MOPONIKA TRADITION IN GORONTALO CITY IN THE PERSPECTIVE OF AL-THUFI'S MASLAHAH
}

\author{
Nency Dela Oktora ${ }^{1}$, Muhammad Yusuf Putra², Nurul Mahmudah ${ }^{3}$ \\ 1, 3 Institut Agama Islam Negeri Metro \\ J. Ki Hajar Dewantara No.15A, Iringmulyo, Kec. Metro Tim., Kota Metro, Lampung 34112 \\ ${ }^{2}$ Universitas Negeri Gorontalo \\ J. Jend. Sudirman No. 6, Dulalowo Tim., Kota Tengah, Kota Gorontalo, Gorontalo 96128 \\ Email: ${ }^{1}$ nencydelaoktora@gmail.com; ${ }^{2}$ yusufmalika@gmail.com; ${ }^{3}$ mafazasyafira@gmail.com
}

\begin{abstract}
This study is aimed at discussing the system and procession of indigenous Mohammed Moponika marriage in creating the value of family harmony in Gorontalo City based on Al-Thufi's perspective on maslahah. This study used in this research is the type of field research with descriptive method of phenomenological approach. The results of this study conclude that in the traditional procession of the Pohutu Moponika Marriage accommodates many aspects of benefit in an effort to give birth to a harmonious family. The value of benefit intended for the Pohutu Moponika tradition is to gain or gain benefits and reject harm in order to maintain goals syara'. Although it is not regulated in the texts and does not seem to be in accordance with the provisions of the texts, the customary process of the Pohutu Moponika Marriage in Gorontalo does not aim to destroy religion. On the contrary, it is actually intended for the benefit of the bride and groom so that they can navigate a harmonious domestic life. Therefore, it is included in the maslahah category in accordance with the concept of al-Thufi. Basically, Allah Swt establishes the rules of command and prohibition that are essentially only intended for the good and benefit of humans.
\end{abstract}

Keywords: Gorontalo; Pohutu Moponika Tradition; al-Thufi's Theory of Maslahah

\begin{abstract}
Abstrak: Penelitian ini membahas tentang sistem dan proses perkawinan adat pohutu moponika dalam menciptakan nilai-nilai keharmonisan keluarga di kota Gorontalo dalam perspektif maslahah Al-Thufi. Penelitian ini menggunakan jenis penelitian lapangan yang bersifat deskriptif dengan pendekatan fenomenologis. Hasil penelitian ini menyimpulkan bahwa proses adat perkawinan Pohutu Moponika banyak mengakomodasi sisi-sisi kemaslahatan dalam upaya untuk melahirkan keluarga yang harmonis. Nilai kemaslahatan yang dimaksudkan pada adat perkawinan Pohutu Moponika ini bertujuan untuk mendapatkan kemanfaatan serta menolak kemudaratan dalam rangka memelihara tujuan syara. Walaupun tidak diatur dalam nash dan terkesan kurang sesuai dengan ketentuan nash, proses adat Perkawinan Pohutu Moponika di Gorontalo tidak bertujuan untuk merusak agama. Sebaliknya, hal itu justru dimaksudkan untuk kemaslahatan kedua mempelai agar dapat mengarungi kehidupan rumah tangga yang harmonis. Hal tersebut termasuk kategori mashlahah yang sesuai dengan konsep al-Thufi. Sebab Allah Swt menetapkan aturan perintah dan larangan pada hakikatnya hanya ditujukan untuk kebaikan dan kemanfaatan bagi manusia.
\end{abstract}

Kata kunci: Gorontalo; Adat Pohutu Moponika; Maslahah Al-Thufi 


\section{Introduction}

Marriage in a society and matters related to it are sometimes influenced by different customs with its own image, and inherited from generation to generation from the legacy of their ancestors, although sometimes it is not relevant to the provisions of Islamic law/ Islamic law and is maintained until However, there is one thing that should be noted, that the arrival of Islam was not aimed at eradicating or eliminating what had been owned by the previous society. and in line with its demands, including customs. ${ }^{1}$

As is the case with the Gorontalo Indigenous Peoples who are known as people who adhere to the Gorontalo philosophical tradition "Adat with the foundation of Syara, Syara with the foundation of the Book of Allah" which contains the meaning of adat based on the Shari'a, and the Shari'a based on the Book of Allah, referring to the Qur'an and the traditions of the Prophet (Al-Qur'an). -Sunnah). In Gorontalo there are quite a lot of traditional ceremonies, of the many traditional ceremonies in question, there is one traditional ceremony that is considered sacred and great which has several stages of implementation, and guidelines that should not be ignored, known as the customary term "Pohutu Moponika" (Traditional Marriage Ceremony) which goes through the stages, namely before, during, and after the main event of the marriage contract. ${ }^{2}$

However, in the author's temporary observation, the author sees that all forms and the many stages of the Pohutu Moponika custom or the traditional marriage of the Gorontalo people, are very costly and detrimental to both parties,

\footnotetext{
1 Kamal Muhtar.Asas-asas Hukum Islam Tentang Perkawinan. Cet.III,Pt Bulan Bintang, Jakarta.1993) p. 13

2 Nurul Mahmudah, "TRADISI DUTU PADA PERKAWINAN ADAT SUKU HULONDHALO” 5, no. 2 (2018): 8.
}

especially for those from the economically weak. Not a few of them delay marriage, for example in the procession between assets or Dutu, which requires the prospective groom to provide certain fruits in order to complete his marriage, and the mandatory color of the traditional wedding dress that cannot be changed, coupled with the high dowry. marriage as an obligation that must be fulfilled by the groom, to be able to edit his prospective bride. In fact, most of the people of Gorontalo embrace Islam. With the many stages of this Pohutu Moponika marriage custom, it is considered burdensome for some people.

Marriage in Islam itself is a very important thing in society. In Islam, marriage is a sunnah of the Prophet Muhammad, for each of his followers are required to follow it. Marriage in Islam is highly recommended, so that the encouragement of biological desires can be channeled in a lawful manner, with the aim of keeping the view and staying away from adultery which is forbidden. This recommendation for marriage has been regulated in the sources of Islamic teachings, namely the Qur'an and AlHadith. $^{3}$

A similar study was conducted by Mardiana (2017) with the title "Marriage Tradition of the Bontolempangan Village Community, Gowa Regency (Acculturation of Islamic Culture and Local Culture)". The discussion carried out by Mariana is the Marriage Ceremony in the village of Bontolempangan. The preparation stage before marriage is carried out such as, deliberation, then the stage of implementing the wedding day, and the postwedding stage. ${ }^{4}$ Wedding parties for Makassar

\footnotetext{
3 Muhammad Saleh Ridwan, Perkawinan Dalam Perspektif hukum Islam dan Hukum Nasional. Cet. 1 Alauddin University Press. 2004. p.3

4 Mardiana"Tradisi Perkawinan masyarakat desa Bontolempangan kabupaten gowa (akulturasi Budaya islam dan Budaya Lokal)".(Makassar, Uin Makassar, 2017).
} 
people, especially in Bontolempangan, are not just an ordinary banquet ceremony, but rather an increase in social status. The merrier a party, the higher the social status of a person. Therefore, it is not uncommon for a family to make a wedding party a place to improve their social status. ${ }^{5}$

Another study by Suharti (2008) with the title "The Kaboro co' $i$ Tradition in the marriage of the Bima Community with Urf Perspective (Phenomenological Studies in the Community of Monta District, Bima Regency). ${ }^{6}$ The discussion contained in the research conducted by Suharti is the factor behind the existence of the Kaboro Co'i tradition in the marriage of the Bima community. This is influenced by two factors, namely first, the kinship factor which is based on the principle of deliberation for consensus in all matters, including here the issue of marriage, and a society that upholds the values of kinship and togetherness. While the second is the factor of cultural customs, agreed upon as the basis for the customary government of Bima.

The difference is that this study uses a phenomenological approach, and this study also focuses more on the study of petungan customs (the selection of a good month for marriage), and does not use the traditional Pohutu Moponika tradition.

\section{Traditional Marriage and Al-Thufi's Theory of Maslahah}

Marriage is one of the most important events in the life of indigenous peoples.

${ }^{5}$ Nurul Mahmudah dan Supiah Supiah, "Study of Sociology in Jurisprudence of Women's Leadership," AlMizan 14, no. 2 (1 Desember 2018): 162-79, https:// doi.org/10.30603/am.v14i2.741.

6 Suharti, "Tradisi Kaboro co’i pada perkawinan Masyarakat Bima Perspektif Urf" (Studi Fenomenologis Pada Masyarakat Kecamatan Monta Kabupaten Bima). (Malang, UIN Malang, 2008).
This incident is not only an incident about those concerned (women and men), but their parents, relatives and families. So there is often an assumption that in general, marriages in Indonesian society, those who marry are actually family with family. An indicator, how many rules must be implemented, rules related to customs that contain religiousmagical nature. ${ }^{7}$

Marriage is a form of eternal life together between a man and a woman which is recognized by the customary alliance and is directed at servants and families. With regard to the proper relationship of this topic, according to customary law, in general in Indonesia, marriage does not only mean a civil engagement but is also a "customary engagement" and is at the same time a kinship and familial bond. So the occurrence of a marriage bond does not only have consequences for civil relations, such as the rights and obligations of husband and wife, joint property, children's position, rights and obligations of parents, but also relates to customary relations. ${ }^{8}$

In Indonesia, customary law applies which regulates the part of marriage whose implementation is in accordance with the customs and habits of a certain place. The law is not widely verbalized, but has a binding nature among these indigenous peoples in the form of moral sanctions/embarrassment when someone behaves inconsistently with the customary law. Starting from a pluralistic culture that creates complex problems, finally customary law is enforced in Indonesia, so that it can represent these problems. Customary marriage law recognizes propriety

7 Trianto Dan Titik Triwulan Tutik, Perkawinan Adat Wulungiri Suku Tengger (Jakarta: Prestasi Pustaka Publisher, 2007), p. 10.

8 Abdul Halik Mone, "Akkorongtigi" dalam Adat dan Upacara perkawinan Suku Makassar, (Makassar: t.p., 2009), p. 1. 
and harmony in association and is religious in nature, does not recognize civil law and public law.

The difference between adat and culture is another matter, and is concerned with the conception that culture has three forms: (1) ideal form; (2) form of behavior; and (3) physical form. Adat is the ideal form of culture. In its full form, we can call it customary behavior.'

Based on the various definitions of marriage above, it can be concluded that marriage is an inner and outer bond between a man and a woman as husband and wife who have legal force and are recognized socially with the aim of forming a family as a unit that promises cultural preservation and fulfillment of interpersonal needs.

The theory of thought 'maslahah' is the key word in an effort to falsify Islam in terms of the Islamic teachings. Al-Syatibi for example in his work Al-Muwafaqat emphasized, "The Islamic teachings are prescribed for nothing but to maintain the benefit of the people in this world and the hereafter". Usul Fiqh scholars systematically do not reach an agreement in providing boundaries and definitions of what maslahah actually is.

Al-Tufi appears different in identifying the position of maslahah in Islamic teachings. AlTufi tends to base the maslahah constellation on the superiority of the human mind. For AlTufi, the vision of reason is more objective in positioning the criteria for maslahah than the antagonism of nashh (teaching texts) between one another. There are at least four ideal foundations that Al-Tufi uses as a foothold in studying and laying the foundations of maslahah theory in Islamic jurisprudence,

9 Koentjaraningrat, Kebudayaan mentalis dan pengembangan.(Pt. Gramedia pustaka utama. (Jakarta, 2008), p.10. which incidentally differs from the number of scholars.

First, the freedom of the human mind to determine the benefit and harm in the muamalat world. The implication is that the determination of benefit or harm in the field of muamalat is enough to do with human upgrading without the support of revelation/ hadith. According to Al-Tufi, human reason alone is sufficient to determine what is maslahah and what is mafsadat (madarat). This creates controversy compared to the opinion of the majority of fiqh experts in general who only recognize the existence of maslahah if it is guided by the principles of texts.

Second, the benefit is a proposition outside the sacred text (verse/hadith). Maslahah is an independent syar'i argument in the sense that the validity of maslahah's validity does not depend on texts. On the other hand, the existence of maslahah can be demonstrated by empirically proving it through customary law. ${ }^{10}$

Third, the object of using the maslahah theory is the laws of social transactions (muamalah) and customary laws ('adah). On the other hand, the study of maslahah, according to this ideal foundation, cannot touch the sacredness of religious rites (worship of mahdah). According to Al-Tufi, matters of pure worship are the rights of the Almighty alone, so that there is no opportunity for humans to reveal the contents of their maslahah. On the other hand, what concerns muamalah and 'adah, Allah SWT surrenders completely for the benefit of His servants. Therefore, the human mind can implement it no matter how the maslahah content contained in it is contrary to the texts. On a

10 Biography of at-tufi dan pemikirannya. http:// makalahmajannaii.blogspot.com/2012/03/at-tufi.html. accessed on 10 January 2013.at 15.00 WIB. 
certain level, Al-Tufi's attitude in this matter has similarities with other figh scholars. At the very least, in examining the maslahah mursalah, the jurists give more or less the same criteria as those proposed by Al-Tufi. Like other scholars, Al-Tufi is of the opinion that the matter of worship belongs to Allah.

Fourth, the benefit is the strongest syara' argument. Al-Tufi does not stipulate that the benefit is a stand-alone argument and is the strongest shari'a argument. So if there is a conflict of revelation or hadith texts with benefits related to muamalah muamalah muamalah issues, the benefit must be prioritized through takhsis or bayan (specialization or explanation). ${ }^{11}$

Fifth, this opinion is not in line with the opinion of the majority of ushul fiqh scholars. According to Al-Tufi, the basis of Islamic law is benefit that can be achieved through reason (thought). According to him, this is in accordance with the content of the Qur'an and Sunnah which encourage humans to use reason optimally. The theory of maslahah al-Tufi, which is likely to oppose qat'i texts, was also adopted by Rashid Rida and one of the modern scholars, Abid alJabiri. Furthermore, al-Jabiri explained that if under certain conditions the benefit conflicts with the sacred texts, then the Companions will prioritize maslahah and delay the implementation of explicit statements from the text. Umar bin Khatab has done many things like this. However, al-Jabiri explained that although maslahah can take precedence when it conflicts with the text or the shari'ah, it does not mean that shari'ah law must change because of changes in maslahah. Sharia law remains upright because it is divine. So here the problem is not ignoring the text, but

11 Zaid, Mustashfa, 1964, al-Maslahah al-Tasyri' alIslami wa Najm al_din al-Thufi, (Kairo; Dar al-Fikr al"Arabi. t.th) p. 85. simply delaying it by looking for another point of view in understanding and interpreting it. ${ }^{12}$

In discussing this concept of benefit, AlTufi is very different from other scholars. Basically, mazab scholars divide benefit into three forms: (1) maslahah mu'tabarah (benefits that are designated directly by the Qur'an or the sunnah of the Prophet Muhammad), (2) maslahah mulgah (benefits that are contrary to the text of revelation or hadith or ijma), (3) al-maslahah al-mursalah (benefits that are not expressly opposed by revelation and hadith). But for At-Tufi, this division does not exist. According to him, because the purpose of shari'ah is benefit, all forms of benefit (supported or not supported by the holy text) must be achieved without going into details like most other scholars.

\section{Indicators for Harmony Family}

Having a harmonious family is the dream of all family members, both father, mother and children. However, building a harmonious family is not an easy matter, many obstacles are faced in running a household that can hinder harmony in a family. Not a few families are unable or fail in their efforts to maintain wholeness, harmony and happiness in the family. Measurements of family harmony include the following: ${ }^{13}$

a) Religious foundation

Strong families always realize that religion is important in supporting family harmony and happiness. Closeness to the creator will shape their personality so that they will get peace of mind, emotions, love and affection.

${ }^{12}$ Thoughts of al-Thufi. http://jondrapianda.blogspot. com/garis-besar-pemikiran-at-thufi. accessed in 11 January 2013 at 15.00 WIB.

${ }^{13}$ Mufidah Ch, Psikologi Keluarga Islam, (Malang : UIN Maliki Press, 2013), p. 52 
b) Love each other

Mutual love will perfect happiness and form a harmony in a family. Although not the only requirement, love still has a very important role to build a strong and lasting marriage.

c) Keeping commitments

A happy and harmonious family is built on a strong and unwavering commitment. This strong and unwavering commitment will keep third parties from interfering in family authority. With this commitment, the main purpose of the family being built can be achieved with the family members themselves. ${ }^{14}$

d) Act realistic

This aspect refers to the facts that occur in fostering family life that are far from what was previously imagined. A harmonious family is a family that is strong and able to adapt by acting realistically without losing hope to achieve a goal in the future.

e) Giving feedback and advising each other

Every human being can make mistakes that can harm himself and his family. In a family, it may be the trigger for the beginning of a rift in the household. Harmonious families have a habit of giving each other feedback and advice with the aim of keeping their loved ones from making any adverse decisions.

f) Cooperation. A harmonious family has a strong cooperation with each of the other family members. They always try to do various activities together. This will create a sense of belonging which further strengthens family ties.

g) Communication. Communication is the

${ }^{14}$ Kamal Mukhtar, Azas-azas Hukum Islam Tentang Perkawinan, (Yogyakarta: Bulan Bintang, 1993), p. 157. main pillar in fostering family relationships. The creation of effective communication in the family further strengthens the inner bond between the family members. Happy families strive to prioritize communication in overcoming problems and making important decisions.

h) Manage the economy well. Most of the time in today's families is to earn a living. It is undeniable that economic factors cannot be underestimated. The ability to manage and manage the family economy wisely is a must so that the family building remains strong, sturdy and able to meet its needs. ${ }^{15}$

Based on the explanation above, the creation of harmony in a family is by trying to maintain wholeness, harmony and happiness in the household.

\section{Method}

The type of research used is field research (field research). This research is descriptive in nature, namely research that seeks to describe a symptom, event, or event that is happening now. In descriptive research, it focuses on the actual problem as it was at the time the research took place. In descriptive research, according to its characteristics, it has certain steps in its implementation, starting with a problem, determining the type of information needed, determining data collection procedures through observation or observation, processing information or data, and drawing research conclusions. ${ }^{16}$ In this study, the author describes the procession

${ }^{15}$ Efendi, Satria, "Hukum Islam : Pelaksanaan dan Perkembangannya di Indonesia, in Ari Anshori and Slamet Warsidi (Ed.), 1991, Fiqh Indonesia Dalam Tantangan, Surakarta; FAI - UMS. p. 61.

16 Soerjono Soekanto, Pengantar Penelitian Hukum, Jakarta: UI-Press, 1986, h. 51. See. Amirudin and Zainal Asikin, Pengantar Metode Penelitian Hukum, (Jakarta: Rajagrafindo Persada, 2006), p. 133 
and traditional marriage system of Pohutu Moponika in creating family harmony, then reviewed with Al-Thufi's maslahah.

This research approach uses a phenomenological approach, the researcher seeks to understand the phenomena that occur in the Pohutu Moponika traditional marriage which is obtained from the data that is needed and which does not need to be re-quantified. The location of this research was conducted in Gorontalo City. With the reason to actualize and reconstruct the paradigm of Gorontalo society in general. In addition, the reasons for guaranteeing access or collecting data that the authors need can be fulfilled properly, making it easier for the authors to search, explore, and analyze data in the community. For data collection using interviews, the author uses a semi-structured method in which the interviewer writes what will be asked in the field. If there are things that must be asked and are not in the question guide, they will ask the informant directly. The following names will be informants in this study:

Tabel 1. Daftar Informan

\begin{tabular}{cll}
\hline No & \multicolumn{1}{c}{ Nama } & \multicolumn{1}{c}{ Status } \\
\hline 1 & Deka Usman & Tokoh Adat (Bate lo Adati) \\
\hline 2 & Rifian Panigoro & Tokoh Adat (Bate lo Adati) \\
\hline 3 & Hasan Ayuba & Tokoh Adat (Bate lo Adati) \\
\hline 4 & Mansur Martam & Tokoh Adat (Bate lo Adati) \\
\hline 5 & Syafrin Ngiode & $\begin{array}{l}\text { Tokoh Agama (Bate lo } \\
\text { Syareati) }\end{array}$ \\
\hline 6 & Meyer tendeann & $\begin{array}{l}\text { Tokoh Agama (Bate lo } \\
\text { Syareati) }\end{array}$ \\
\hline 7 & $\begin{array}{l}\text { Firmansyah } \\
\text { Kobandaha }\end{array}$ & $\begin{array}{l}\text { Tokoh Agama (Bate lo } \\
\text { Syareati) }\end{array}$ \\
\hline 8 & Ahmad Zaenuri & $\begin{array}{l}\text { Tokoh Masyarakat (Bate lo } \\
\text { Tau) }\end{array}$ \\
\hline 9 & $\begin{array}{l}\text { Mohammad Zainul } \\
\text { Arifin }\end{array}$ & $\begin{array}{l}\text { Tokoh Masyarakat (Bate lo } \\
\text { Tau) }\end{array}$ \\
\hline
\end{tabular}

a. Deka Usman is a Gorontalo traditional leader. He serves as the I (one) customary holder in the city of Gorontalo at this time, not infrequently he often attends several Gorontalo traditional events.

b. Rifian Panegoro is a Gorontalo traditional leader who serves as the II (two) customary holder in the city of Gorontalo.

c. Hasan Ayuba is a traditional leader and local language teacher at SDN 82 Gorontalo City.

d. Mansur Martam is one of the traditional leaders of Gorontalo and also a lecturer in Indonesian Literature at the State University of Gorontalo.

e. Syafrin Ngiode is a religious figure who is also the head of the KUA in Kota Tengah sub-district, Gorontalo city.

f. Meyer Tendean is a religious figure who is often active in filling out studies at several mosques in Gorontalo City.

g. Firmansyah Kobandaha is a religious figure who is also a lecturer at IAIN Gorontalo.

h. Ahmad Zaenuri is a community leader and as RT in Kota Tengah sub-district.

i. Mohammad Zainul Arifin is a community leader as well as a sub-district head in Kec. the city of Central City of Goronalato.

Basically, ten informants were interviewed, but after the data was obtained, similar data were found from the informants' answers. The same data is not included in the data exposure because the data is exactly the same. so the researcher only included 9 informants whose answers and responses were different.

Cases like this often appear in field research, the data obtained produce the same answer, so that in research methodology, this data is called saturated data. Saturated data in the study is not included in the writing, only 
given information that the data is saturated data. The sampling method used is snowball sampling. This snowball method is basically a method that provides recommendations to researchers by informants to recommend other people who are the main informants to get more valid data.

\section{Result adn Discussion}

Gorontalo City is the capital city of Gorontalo Province, Indonesia. The city of Gorontalo was born on Thursday, March 18, 1728 AD or coincided with Thursday, 06 Syakban 1140 Hijriah. On February 16, 2001, Gorontalo City was officially designated as the capital city of Gorontalo Province (Law No. 38 of 2000 Article 7). The city has an area of $66.25 \mathrm{~km}^{2}(0.55 \%$ of the area of Gorontalo Province) and a population of 134,931 people (based on SP 2017 data) with a population density of 2,718 people $/ \mathrm{km}^{2}$. This city has the motto "Indigenous with Syara', Syara' Bersendikan Kitabullah" as a way of life of the people that combines customs and religion.

Before the formation of Gorontalo Province, Gorontalo City was part of North Sulawesi Province. Gorontalo is a Municipality which was officially established on May 20, 1960, which later changed to Kotamadya Gorontalo in 1965. The name Kotamadya Gorontalo remained in use until 1999. Furthermore, since the enactment of Law Number 22 of 1999 concerning Regional Government, where the term Kotamadya is no longer used, it is replaced with Kota, then Gorontalo has adjusted its name to Kota Gorontalo until now.

The people of Gorontalo City Almost all of the population adheres to Islam. Of the total population of 147,354 people, a total of $70 \%$ of the population in the city of Gorontalo are Muslims while 30\% are Christians, Catholics and the like. The number of facilities and places of worship for Muslims in Gorontalo City has hundreds of mosques and prayer rooms.

Education is an important thing in advancing Human Resources which can have a long-term effect on improving the economy. With a high level of education, it will boost the level of community skills which in turn will encourage the growth of entrepreneurial skills and new jobs, so that it will assist government programs in eradicating unemployment and poverty.

Indicators that show improvement and increase in the quality of education are the increase in the net enrollment rate (NER), the increase in the gross enrollment rate $(\mathrm{APK})$, and the decrease in the dropout rate. The increase in human resource capacity through the GER and NER target indicators between 2016-2017 indicates an increase in the expansion of educational opportunities at various levels, which is marked by an increase in the Gross Enrollment Rate and Net Enrollment Rate.

The Gorontalo Indigenous Peoples have a special view of marriages that have terms and moral values. The customary system is to adopt the Patrilineal system, which is a community custom that regulates the flow of descent from the father's side. This word is often equated with patriarchy or patriarchy, although it basically means different. Patrilineal comes from two Latin words, namely pater which means father, and linea which means line. This is reflected in the uniqueness of the traditional marriage ceremony of the people in Gorontalo. The first stage is called Mopoloduwo Secret, which is where the parents of the man come to the residence of the woman's parents to get their child's marriage blessing. If both agree, then a time is determined for the proposal or 
Tolobalango. According to the narrative and views of Ahmad Zaenuri:

"Tolobalango is an official proposal which is attended by the traditional officials of the State Government and their families through the spokesman for the male family or Lundthu Dulango Layio and the spokesperson for the female family envoy or Lundthu Dulango Walato. In the Gorontalo Customary Proposal, it is not allowed to mention the cost of marriage (Tonelo) by the envoy of the groom's family, but the most important thing is to reveal the Mahar or Maharu and the delivery of the next event to be carried out. The recital of rhymes that reciprocate is an illustration of the value of the customary wealth owned by Gorontalo, as for the purpose of not disclosing the costs of marriage, so as not to make the momentum of marriage a place to show off one's abilities or pleasure". ${ }^{17}$

At the agreed time in the Tolobalango event, the next procession is to deliver the treasure or between dowries, in the Gorontalo area called Depito Dutu which consists of 1 dowry package, a complete package of traditional Gorontalo cosmetics and modern cosmetics, plus a set of bride's clothing, as well as various fruits. fruits and spices or dilonggato. Mansur Martam expressed his views:

"At the time of delivery of the dowry, all these dowries were loaded in a vehicle decorated to resemble a boat called the Kola-Kola. This delivery procession is carried from the Yiladiya house (residence/king's house) of the groom to the bride's Yiladiya house accompanied by traditional drums and the Tinilo group accompanied by tambourine beats singing traditional Gorontalo songs that have been passed down for generations, which contains flattery, appeals, and prayers with the intention of bringing safety in the

17 Ahmad Zaenuri, Public Figure (Bate lo Tau), Interviewed in 10 June 2018. married life of the world and the hereafter to the bride and groom. ${ }^{18}$

On the night of the day before the marriage contract, a series of engagement night events or Mopotilandahu are held. This event begins with Khatam Qur'an, this process means that the prospective bride has completed or completed the Koran by reading "Wadhuha" to Surat Lahab. Followed by Molapi Saronde, which is a dance performed by the prospective groom and father or male guardian. This dance uses a scarf. The father and the groom take turns dancing to it, while the bride and groom watch from a distance or from the room.

For the prospective groom, this is a means to see or peek at his future wife, the term for the Gorontalo area is called Molile Huali. With this dance the groom-to-be steals glances to see his candidate. Saronde begins with the beating of the tambourine accompanied by the song Tulunani, which is composed of poems in Arabic which is also a chant of prayers for salvation. Then the bride-to-be, accompanied by a companion, performs the traditional Tidi Daa or Tidi Loilodiya dance. According to Rifian Panigoro's narrative:

"This dance depicts the courage of a household. After dancing the Tidi Dance, the prospective bride sits back down the aisle and the groom and his entourage of traditional leaders and their families return to their homes." ${ }^{19}$

The next day, the Customary Stakeholders carry out the marriage contract, as the culmination of the event where the bride and groom will be united in a legal marriage bond according to Islamic Shari'a. In a half-squat

\footnotetext{
18 Mansur Martam, Adat Figure (Bate lo Adati), Interviewed in 14 June 2018

19 Rifian Panigoro, Adat Figure (Bate lo Adati), interviewed 20 July 2018
} 
manner, the groom and the head of the village make a vow of Ijab Kabul and a dowry that has been agreed upon by both families. The event was then closed with a prayer as a sign of gratitude for the smooth running of this wedding ceremony.

Basically all of the residents of Gorontalo society mostly embrace the teachings of Islam, so their customs are strongly influenced by Islamic teachings and rules, including in terms of marriage, this is as conveyed by Deka Usman as a traditional figure:

"In principle, it is very clear that indeed Gorontalo is the majority of Muslims, so almost all customary processes are carried out using customary processes which are essentially not contrary to Islamic law. , where they absolutely do not invite people to abandon their ancestral cultural customs but to improve them so that nothing is contrary to the Shari'a. Therefore, the people of Gorontalo adhere to the traditional motto "Adati hula hula Sareati - Sareati hula hula to Kitabullah" which means, "Indigenous together" syara, syara based on the Book of Allah". ${ }^{20}$

As for acculturation and integration of sharia and culture in the context of Gorontalo traditional marriages, Hasan Ayuba explains as follows:

"An example of how is when the Shari'a tries to merge itself in the traditional beliefs of the Gorontalo Marriage tradition, such as Akadji ${ }^{21}$ or what is popularly known to our community to cancel the ablution water, at first before Islam entered Gorontalo, to cancel the ablution water or Akadji, the process is for the groom to use pig's blood. then touched and marked the crown of the

20 Deka Usman (Bate lo adati) Adat Figure Kota Gorontalo, Interviewed in 27 June 2018.

${ }^{21}$ Akadji is a kabul ijab process where in gorontalo custom, the groom will be guided by the customary ruler to pledge the marriage agreement. bride, but this was no longer valid when the da'wah of the aulia and ulama entered Gorontalo, especially after King Sultan Amai $^{22}$ embraced Islam, the pig's blood was considered contrary to sharia, so it was replaced with blood halal chicken. ${ }^{23}$

From the descriptions of Deka Usman and Hasan Ayuba above, it can be understood that the influence of Islam has become an unwritten law in Gorontalo which also regulates all the lives of its people, including marriage customs. However, it can be seen that the uniqueness of the traditional marriage tradition in Gorontalo lies in the sacredness of the traditional procession or the rules that must be obeyed based on existing guidelines, this is as conveyed by Firmansyah Kobandaha:

"Why do many say that the Gorontalo marriage custom is very stunning and very unique, that's because it lies in customary rules that are not arbitrary and quite strict, where families who have intentions must follow the existing standards as left by the predecessors. For example, in the choice of colors, for example, some colors such as white and blue are considered as expressions of mourning, so they are taboo to be used for traditional marriages. Meanwhile, on the fingernails of the bride, it is similar to the Palembang bride's nail hisan. ${ }^{24}$

The information that has been conveyed above turns out to be a bit ambivalent when compared with what was conveyed by Mansur Martam below:

\footnotetext{
${ }^{22}$ King Sultan Amai was the great King of Gorontalo who first embraced the teachings of Islam, his influence on the spread and da'wah of Islam in Gorontalo was very large because of the factor of his power and the people's love for his leadership model as king..

${ }^{23}$ Hasan Ayuba (Bate) Adat Figure Kota Gorontalo, Interviewed in 15 June 2018.

24 Firmansyah KobandahaPublic figure (Bate lo Syareati), interviewed in 15 June 2018.
} 
"Indeed, basically the customary rules of marriage must follow the existing standards, for example the bride and groom also need to learn a short dance, because there is a traditional ritual that requires the groom to show his dancing skills and throw a scarf. The bride is like that, she must be good at holding tools such as swords, while dancing in front of the aisle. However, if one of them is really unable or unable to dance, then he is forced and may be replaced by a younger brother, cousin, or other family members. and it should be noted that the predecessors of traditional leaders and religious leaders did not dispute this, because they saw that this was a custom that did not conflict with the Shari'a, meaning that as long as aqidah is not mortgaged, there is no problem" ${ }^{25}$

The information presented by Mansur Martam seems to be quite correlative, relevant, and interconnected with the context of the problem, compared to what is conveyed by Hasan Ayuba who tends to be a bit conservative. The researcher then analyzes and draws a common thread between the two that normatively the customary rules of Gorontalo marriage must be obeyed, but in the context of benefit or in very unlikely circumstances, it is allowed to take solutive and conditional alternatives, for example, for the task of dancing, cousins can replace them. , brother, sister, or other family members, if one of the bride and groom is disabled or cannot dance at all, this reason is as added by Rifian Panigoro:

"If the issue of color is indeed a taboo subject when the bride and groom use white and blue, but if for example there is only color, isn't it possible for the wedding procession to be canceled? and allow it as long as the reason is really emergency. While dancing, we obviously cannot force it, for example

25 Hasan Ayuba, Adat Figure (Bate lo Adati), interviewed in 16 June 2018. one of the bride and groom has a physical disability, or maybe he can't dance at all, because this dance takes a long time to practice, especially the traditional Gorontalo dance, so we as traditional leaders, religion, and society put the benefit of the people first. The thing that doesn't make sense is just because of the dance, then the bride and groom don't get married, even though if we look back, this marriage is obligatory while the others are only complementary." 26

Examining the context above, the researcher concludes that in principle it is the priority scale and benefit values that must be prioritized, as in the Maqosid al-Syariah analogy that maintaining religion must take precedence over taking care of oneself, and taking care of oneself must take precedence over taking care of offspring, so the concept of this priority scale is not can be implemented in reverse, for example if one of the bride and groom cannot dance then there will be no marriage between the two, according to this researcher is a paradigm that needs to be reconstructed.

Philosophically, the religious culture of the people in Gorontalo City recognizes its existence as the porch of Medina. As for the term "Adat Bersendikan Syara', Syara' Bersendikan Kitabullah" basically grows and becomes an inseparable part in the process of struggle between religion and culture that occurs in almost all regions of the archipelago in the process of structural Islamization (top down). Likewise in Gorontalo City, in the local language, the term is "Adati Hula-Hulaa To Saraa, Saraa Hulahulaa To Qur'ani”. This term comes along with the development of Islamization which does not want to clash between adat and Islamic teachings in a frontal manner.

26 Rifian Panigoro, Adat Figure (Bate lo Adati), interviewed in 12 July 2018 
The benchmark of this theocentric view is religious belief which is followed up by practice and a God-centric mindset. So that with the actualization of faith and charity that are inseparable, the culture and civilization produced by humans will also be oriented to the God-centric paradigm, namely culture and civilization that are not trapped in the shackles of irrational and damaged culture. As explained by Syafrin Ngiode:

"If it is felt that the procedures for the Gorontalo Marriage custom have deviated from the Shari'a or Islamic religious provisions, then as religious leaders, we will synergize with the traditional elders to be able to evaluate the marriage custom, because customs and religion should not conflict with each other." ${ }^{27}$

However, the will to make changes at least still takes an accommodative and tolerant attitude towards the implementation of traditional marriages that are rooted in community culture, so that customary and syara' marriages can run together. This attitude is intended to avoid chaos that can destabilize the joints of social life. From a sociological perspective, local wisdom held by the Gorontalo people as a way of life is actually a form of Islamic acculturation to local culture. Although basically it is a creative and innovative process in order to expand the horizon of Islamic culture. An incomplete or fragmentary understanding of it sometimes invites a regressive reaction. Nevertheless, the Mujtahids of Gorontalo seem to aim at providing space for the creative process and acculturation of Islam through cultural offerings. It is intended that the use of Gorontalo customary marriages as a source of law does not need to be contested, because Gorontalo is an area that has its own sociohistorical uniqueness which is different from

27 Syafrin NgiodePublic figure (Bate lo Syareati), interviewed in 17 July 2018. the social origin of the birth and existence of Islam from its original place (Saudi Arabia).

The main purpose of the obligation to give the dowry is to show the sincerity (shidq) of the husband's intention to marry his wife and place her on a noble degree. By requiring this dowry, Islam shows that women are creatures who deserve respect and have the right to own property. Furthermore, whether this dowry needs to be mentioned in the marriage contract, or not, the answer can be found in Sheikh Muhammad bin Qasim, in Fathul Qarib:

"It is Sunnah to mention the dowry in the marriage contract... even if it is not stated in the contract, the marriage will still be considered valid". ${ }^{28}$

Furthermore, in the book of Fath al-Qarib it is explained that there is no minimum and maximum value in the dowry. The provisions in this dowry are anything that is legal to be used as a medium of exchange. Whether in the form of goods or services, it is legal to be used as a dowry. But the dowry is not less than 10 dirhams and not more than 500 dirhams. One dirham is equivalent to 2,975 grams of gold. Thus, it can be understood that there is no minimum stipulation regarding dowry, even in a hadith the Prophet once stated that even a ring made of iron can be a dowry.

In another statement, the Prophet also mentioned that the best woman is the one with the cheapest dowry. This shows that the dowry is not the main purpose of a marriage, and the nominal standardization is adjusted to the conditions of each party. a woman, and not more than 500 dirhams, because more than that will show the arrogance of

28 Syekh Muhammad bin Qasim in Fathul Qarib (Surabaya: Kharisma, 2000), p. 234. The texts are:

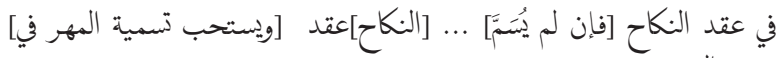
[صح العقد[مهر: 
each party. Dowry can also be in the form of services, such as services for teaching reading the Qur'an, and other services. ${ }^{29}$

In the context of the traditional marriage of Pohutu Moponika, the researcher sees that the original Gorontalo traditional view does not rely on material (wealth). In the words of Gorontalo's cultural wisdom it is mentioned wonu opiohe lo loqia penu dila to doiya, wonu opiohe lo dudelo penu dila motonelo. 'If you speak well, you don't use money', if you are good, you don't bring possessions. The meaning reflected in the wise words is that the Gorontalo people prioritize character over property (material). In addition, there are also parents who have the view of wanting to elevate the status of others. As stated by Mohammad Zainul Arifin:

"If the child is a girl, then the amount of the dowry is adjusted to the ability of the man. If the child is a man, then the marriage is endeavored to raise the status of his wife's family. This view is highly recommended in religion. Moreover, in the current condition our society is being entangled by the monetary crisis. Of course, the amount of the dowry is adjusted to these conditions, so as not to embarrass the families of both parties." 30

The dowry is usually accompanied by something in the form of a 'follow-up' Tunuhio, namely U Poqo-Poqo: Yo Wau U Oli:Oliyoqo 'the silent one' in the form of a sack of rice, 'and the moving one' in the form of a cow, Ilata Wau Bolunggodu 'tustel and entertainment', U Ohuloqa Wau u uwantu 'the bride and groom's wedding dress and

\footnotetext{
${ }^{29}$ Nurul Mahmudah, "ASPEK SOSIOLOGIS DALAM PUTUSAN PENGADILAN PADA PERKARA CERAI GUGAT,” Nizham Journal of Islamic Studies 7, no. 01 (12 July 2019): 106-22, https://doi.org/10.123459/nizham. v7i01.1522.

${ }^{30}$ Mohammad Zainul Arifin, Public Figure (Bate lo Tau), interviewed in 1 July 2018.
}

aisle'. This set of requirements applies to everyone if agreed by certain parties.

It can be concluded based on the concept of benefit that the amount of dowry is always associated with (1) the position of the girl's family; (2) the ability of the male side; (3) efforts to elevate degrees, (4) approval and agreement of both parties.

\section{Process of Modepita Dilanggato}

The status of Dilonggato is the same as the status of maharu in the marriage ceremony. For this reason, it is obligatory for a man to fulfill it in accordance with the results of the deliberation of the parents of both parties. According to Firmansyah Kobandaha, as a religious figure (Bate lo Syareati):

"Dilonggato is a set of food ingredients or consumption for organizing a wedding party, which consists of a sack of rice, a cow, goat, chicken and so on as far as the family of the man can afford. The food items that are delivered are equipped with spices that are adjusted to the delivered cows (if any). Other equipment in the form of perfumes and powder as well as equipment for preening. Dilonggato material has now been adapted to the venue for the party. If the festival is held at the bride's house, then the materials mentioned above must automatically be available. If the party is held in a rented building, then the dilonggato is no longer in the form of material but has been replaced with some money. This is a form of cultural change." ${ }^{1}$

According to researchers, it turns out that material things and parties quickly change and adapt quickly to developments. Idea and philosophical things can last a long time. So, the venue for the party also affects material things. This means that if the venue for the

31 Firmansyah Kobandaha Public figure (Bate lo Syareati), interviewed in 19 June 2018. 
party changes, the material dilonggato will also change.

\section{Process of Mopotuluhu}

The mopotuluhu 'put to sleep' event can be known through the madepita dilonggato event, because along with the dilonggato material there is an alumbu yilulupa 'egg yolk blanket' as a marker that the groom will spend the night at the bride's house on their wedding night. Even if it is approved. If the mopotuluhu event is approved to be held, then the groom will be rested to huali lo humbia 'bridal room' at the bride's house. The groom wore an egg yolk blanket that had been provided there. Rifian Panigoro, Traditional Leader (Bate lo Adati):

"Sleeping at the bride's house does not mean the groom sleeps completely that night, but only in order to take the blanket prepared in the room. Towards dawn around 23:00 the groom secretly left his room and then fled with a blanket to his house. This is meant to give the impression that he ran away the blanket that was lent to him. The sarong will be returned at the marriage ceremony, which they then use to sleep together as husband and wife. The next morning, the sarong is brought by the man to be shown to his parents, and if the sarong has stains, then both parents welcome it happily because it turns out that the girl his son married is a girl who is still pure (still a virgin) ". 32

Based on the statements of the informants above, the researcher underlines the last sentence about the husband who reports his wife's virginity, while the husband's parents welcome him. In the Mopotuluhu custom, this is actually in the opinion of the author seen as something that actually does not need

32 Rifian Panigoro, Adat Figure (Bate lo Adati), interviewed in 20 June 2018. to be carried out on the basis of benefit, because along with the development of the modernization era and the progress of the times, traditional processions like this are considered no longer relevant, especially if it turns out that the woman who is married is already married. not a virgin, then automatically the risk of harm that will be caused is much greater, for example early divorce, violation of agreements that have been built, or conflicts due to offense, and so on. This, of course, is not desired by both parties. The researcher also assumes that this is not at all against the conception of the Shari'a and will not become a problem from the perspective of adat if it is not done. Similarly added by Syafrin Ngiode as a Religious Leader:

"I think that according to the Mopotuluhu tradition, it is no longer necessary for the man to go and deposit a yellow cloth on his parents which are stained with virginity so that his parents know that the woman he marries is still a girl, now what if the man married is a girl? who is not a virgin, do both partners have to divorce immediately?, this is irrational, more than that I think this does not accommodate the value of justice ideally, because it could be that virginity is only a benchmark for a harmonious family, while virginity is not. Between men have rights and obligations to be treated fairly according to their respective portions. In addition, the era is increasingly modern and developing, it is possible for the woman to use watercolors, or dyes and so on, from this statement the next question arises, now what about those who are already married for reasons of pregnancy, do they still need to deposit a yellow cloth filled with virginity stains? "33

\footnotetext{
${ }^{33}$ Syafrin NgiodePublic figure, interviewed in 12 July 2018
} 


\section{Process of Moponika}

The stage of 'marry' moponics. The word moponikan comes from the word nika 'marriage' which means to justify a woman's body which was previously forbidden to have intercourse. The moponika stage is the inauguration, announcement, and inauguration of a young couple to establish a household. Therefore, the wedding ceremony must be attended by elements of the local government, the entire family, and the entire surrounding community, as public witnesses. Mohammad Zainul Arifin said:

"In Gorontalo's cultural perspective, the presence of family, relatives, neighbors and the community to the Marriage Council is nothing but to strengthen community relations and provide testimony and prayers of blessing for the planned marriage to be held. Marriages that are directly carried out not based on local customs will make it difficult for the community to approve. In fact, marriages that are carried out briefly without going through the customary process will cause unpleasant rumors in the community, ranging from allegations of cohabitation, adultery, and so on". ${ }^{34}$

The event on the wedding day follows a certain order in the traditional ceremony. This event is the culmination of the stages that are passed in the marriage process according to Gorontalo customs. The language used as the medium is language in the form of tujaqi 'traditional poetry', in this case tujaqi directions.

In the perspective of Maslahah At-Thufi, the purpose of the Pohutu Moponika Marriage traditional ceremony is part of the preservation of existing cultural values, because basically the researcher sees that in the Pohutu Moponika

${ }^{34}$ Mohammad Zainul Arifin, Public Figure (Bate lo Tau), interviewed in 21 July 2018.
Marriage traditional procession, many aspects of benefit are accommodated in an effort to give birth to a harmonious family. The value of the benefit intended in the Pohutu Moponika Marriage custom is aimed at achieving or obtaining benefits and rejecting harm in order to maintain and maintain the goals of syara'. The traditional procession of the Pohutu Moponika Marriage does not aim to destroy religion, on the contrary it is intended to raise and uphold the noble values and teachings of Islam so that the bride and groom can navigate the life of the household in harmony and always be under the protection and grace of Allah SWT.

The building of shari'a and adat relations in the context of the Pohutu Moponika traditional marriage takes place side by side, and harmoniously, where Islam is the most important part of the customary marriage procedure. So no matter how strong the community clings to their traditional traditions, it does not make them immediately separated and uprooted from the religious values that have been embedded in them.

Furthermore, the legal system entity will lead to a point of universal cultural value, namely the realization of a sakinah, mawaddah, and rahmah marriage or in other terms called happiness. There are several tug-of-war processes in the traditional Pohutu Moponika marriage procession, but not in the form of defeating or denying each other, but is a process of giving each other in the corridor of mutual acceptance which is deemed appropriate. Islam does not eliminate local traditions as long as these traditions do not conflict with pure Islam, but Islam also does not destroy local traditions that still have relevance to the great Islamic tradition. The accommodative and flexible contact of adat and Shari'a at the Pohutu Moponika Marriage ceremony forms a collaborative Islamic spectrum, namely the 
relationship between Islam and local culture with an inculturative pattern as a result of joint construction between agents (local elites) and the community in a dialectical process. which happens continuously.

Thus, the genuinity or locality of Islam is essentially the result of the local community's social construction of Islam which came to him when there was already an established culture in the region. Islam has indeed come to an area that is not a cultural vacuum. Therefore, when Islam comes to certain areas, local construction also participates in building Islam as it is today.

The phenomenon of the traditional marriage of Pohutu Moponika has a very unique and interesting dimension, marriage on the one hand is a religious order with all its provisions, while on the other hand it has a dialectic with the socio-cultural reality that lives in one place. The study of the dialectic between Islamic law and customary law is an entry point that actually Islamic law does not always conflict with customary law or traditions of a region. In this context, Islamic law proves itself as a law that can be dialectic with the reality of the times and socio-cultural conditions in society.

In addition, the study of Islamic law, especially marriage which is sociological in nature, is able to produce a legal value that is needed by the community. It is not only theological-normative, but also addresses sociological-historical aspects. That is, a law that is in accordance with religious norms and is also representative of sociological values.

Furthermore, the legal system entity will lead to a point of universal cultural value, namely the realization of a sakinah, mawaddah, and rahmah marriage or in other terms called happiness. There are several tugof-war processes in the traditional procession of the Pohutu Moponika Marriage, but not in the form of defeating or denying each other, but is a process of giving each other in the corridor of mutual acceptance which is deemed appropriate. Islam does not eliminate local traditions as long as these traditions do not conflict with pure Islam, but Islam also does not destroy local traditions that still have relevance to the great Islamic tradition.

In addition, the study of Islamic law, especially marriage which is sociological in nature, is able to produce a legal value that is needed by the community. It is not only theological-normative, but also addresses sociological-historical aspects. That is, a law that is in accordance with religious norms and is also representative of sociological values.

\section{Conclusion}

Basically, the procession and traditional marriage system of Pohutu Moponika aims to create long-term family harmony. When viewed from al-Thufi's maslahah, it appears in principle and the priority scale and benefit value that must be prioritized. Based on the stratification of 5 things that need to be guarded, then maintaining religion must take precedence over taking care of oneself, and taking care of oneself must take precedence over taking care of offspring. The accommodative and flexible contact of adat and shari'a at the Pohutu Moponika Marriage ceremony forms a collaborative Islamic spectrum, namely the relationship between Islam and local culture with an inculturative pattern, as a result of joint construction between agents (local elites) and the community in a process. continuous dialectic. Therefore, the traditional Pohutu Moponika Marriage procession in Gorontalo, although not regulated in the texts and seems to be outwardly inconsistent with the provisions of the existing texts, but because 
it does not aim to destroy religion, on the contrary, is intended for the benefit of the bride and groom so that they can navigate a normal household life. harmonious, then this is included in the maslahah category in accordance with the concept of al-Thufi. Because basically, Allah swt sets the rules of command and prohibition, actually only intended for the good and benefit of humans.

\section{References}

Arikunto, Suharsimi. Manajemen Penelitian, Jakarta: PT Rineka Cipta, 2011, Cet. ke-13.

Ayuba, Hasan. Tokoh Adat (Bate lo Adati), interviewed in 16 June 2018.

Eriyanti, Nahira, Mediasi, Gudang Ilmu (Online), (http://naharaeriyanti.blogspot.com), accessed in 23 September 2015.

Fahimah, Iim. "Akomodasi Budaya Lokal ('Urf) Dalam Pemahaman Fikih Ulama Mujtahidin”, Jurnal Ilmiah Mizani, Vol. 5, No. 1 (2018).

Hairunisa, Karim, Titin Samsudin. "Peran Perempuan dalam Adat Istiadat Gorontalo", AS-SYAMS, Vol. 1, No. 2 (2020).

Hamdani, Damin. Makalah Hukum Perdata Islam, Al-Shulh (Perdamaian) (Online) (Daminhamdani.blogspot.co.id), accessed in 13 September 2015.

Hamid, Zahry. Pokok-Pokok Hukum Perkawinan Islam Dan Undang-Undang Perkawinan Di Indonesia, Yogyakarta: Bina Cipta, 2019.

Hosen, Ibrahim. "Memecahkan Permasalahan Baru", dalam Jalaluddin Rahmat, Ijtihad Dalam Sorotan, Bandung: Mizan, 2008. Cet. ke-5.

Husnan, Moh. Ihsan. "Pohutu Momulanga: Gelar Adat di Gorontalo", AL-ULUM, Vol. 12, No. 1 (2012)

http://www.hukumonline.com/berita/baca/ lt56bb2d4541fd5/ini-poin-penting-yangdiatur-dalam-perma-no1-tahun-2016, accessed in 23 August 2018.
Jibu, Supriyanto Agus, Muhamad Taufik Kustiawan, "Pergeseran Nilai Adat Dan Budaya Dalam Perkawinan Masyarakat Gorontalo Di Masa Pandemi Covid-19”, AHKAM Jurnal Hukum Islam, Vol. 9, No. 1 (2020)

Kobandaha, Firmansyah. Tokoh Agama (Bate lo Syareati), interviewed in 15 June 2018.

Mahmudah, Nurul, Supiah Supiah. "Tradisi Dutu Pada Perkawinan Adat Suku Hulondhalo Di Kota Gorontalo Perspektif Maqāshid AlSyarìah”, Jurnal Ilmiah Mizani, Vol. 5, No. 2 (2018)

Mahmudah, Nurul. “Aspek Sosiologis Dalam Putusan Pengadilan Pada Perkara Cerai Gugat", Nizham Journal of Islamic Studies 7 , no. 01 (12 Juli 2019): 106-22. https://doi. org/10.123459/nizham.v7i01.1522.

Mahmudah, Nurul, dan Supiah Supiah. "Study of Sociology in Jurisprudence of Women's Leadership", Al-Mizan, Vol. 14, no. 2 (2018). https://doi.org/10.30603/ am.v14i2.741.

Malik, Adi Yusfi. Tradisi Perkawinan Didekat Mayit Dalam Perspektif Hukum Pernikahan Islam. Malang: UIN Malang, 2012.

Martam, Mansur. "Pohutu Moponika Dalam Perspektif Hukum Islam (Studi Kasus Adat Pernikahan Masyarakat Gorontalo)", ISTI'DAL, Vo. 4, No. 1 (2017)

Mone, Abdul Halik. "Akkorongtigi" dalam Adat dan Upacara perkawinan Suku Makassar, 2013.

Ngiode, Syafrin. Tokoh Agama (Bate lo Syareati), interviewed in 17 July 2018.

Orinton, Kumpulan Artikel Hukum, Mediasi Perbankan sebagai Alternatif Penyelesaian Sengketa di Luar Pengadilan (Online). Orintononline.blogspot.com, accessed in 13 September 2015.

Panigoro, Rifian. Tokoh Adat (Bate lo Adati)Kota Gorontalo, Interviewed in 15 June 2018.

Qasim, Syekh Muhammad bin. Fathul Qarib, Surabaya: Kharisma, 2000. 
Rumah Bangsa Foundation, Syarat Hakam (Online), http://agenmakalah.blogspot.co.id, accessed in 07 July 2018.

Sabiq, Sayyid. Figh al-Sunnah, T.tp: Dar alTsaqafah al-Islamiyah t.th, jilid II.

Saifullah, Metode Penelitian. Malang: Fakultas Syariah, 2016.

Sastroatmodjo, Arso. Hukum Perkawinan Islam, Jakarta: Bulan Bintang, 2011.
Tendean, Meyer. Tokoh Agama (Bate lo Syareati), Interviewed in 16 June 2018.

Trianto, Tutikdan Titik Triwulan, Perkawinan Adat Wulungiri Suku Tengger, Jakarta: Prestasi Pustaka Publisher, 2007.

Zuhaily, Wabah al-. al-Figh al-Islami wa Adillatuhu, Damsyiq: Dar al-Fikr, 1984.

Zuhri, Saifudin. Akal Sebagai Sumber Hukum Islam, Yogyakarta: Pustaka Pelajar, 2011. 